68-71

Jaroslav Sedlák

\title{
Transformace měst v postsocialismu
}

Klíčová slova: Sídliště; Regulace; Uniformita.

Kontakt: jarryn@centrum.cz

Školitel: Gabriel Kopáčik

Tematický okruh: Urbanismus

Transformations of Cities in the Post-Socialist Era

The dissertation thesis explores the transformations and new urban structures of housing estates built in the Socialist era. It focuses namely on the decades of transformation of society after the collapse of the Socialist system, when the influence of Western lifestyles and the geopolitical climate changed the way modern Socialist housing development in the Eastern bloc was perceived. 
Dizertační práce zkoumá vznikající proměny a urbánní novotvary v sídlištních čtvrtích městských struktur vybudovaných v období socialismu. Zaměřuje se zejména na dekády přerodu společnosti $v$ době po pádu socialistického systému, kdy vlivy západního způsobu života a geopolitické klima změnily nahlížení na modernistickou socialistickou výstavbu ve východním sektoru.

Příspěvek bude tematizovat proces užívání sídlištních částí měst v ekonomicky méně výkonných státech, než je ten náš (bývalé republiky SSSR - Gruzie, Moldávie, Arménie, Ukrajina atd.), objevíme zcela jiný průběh vývoje takovýchto lokalit. Již v roce 1985 je v Gruzii legalizováno státním aparátem individuální rozšiřování obytného prostoru na náklady majitelů bytů, nebot tehdejší produkce nestačila prostorově nasytit tehdejší poptávku. Vysokopodlažní domy na sídlištích se tak rozvíjely expanzivním způsobem do podoby nejrůznějších mutací přístaveb a „obstaveb“ atd. Po rozpadu Sovětského svazu v roce 1991 přechází celý princip volného dostavování v neřízený proces. Jedná se o dobu přechodu k neomezenému kapitalismu s rostoucí nezaměstnaností. Nový ekonomický systém sice rozrušil sovětskou urbanistickou strukturu tzv. mikrorajonu, ale s rozvojem drobného individualismu soukromého sektoru se proměňuje i podoba sídlištního

města. Celkový ekonomický kolaps a absence prostorových regulací začaly v sídlištích nabízet přístupnou variantu bydlení i místa k podnikání. Začínají se objevovat kiosky a postupně se rozrůstající partery městského typu. Současně vznikají nové představěné ulice reagující na přílišné rezervy a vzdálenosti, stejně

tak se objevují vertikální ulice uvnitř domů. Stavba samotná už není pouze místem k bydlení, ale mnohé byty jsou využívány jako kanceláře. Rozvíjí se služby a celková hodnota diverzity prostředí začíná rapidně narůstat. Charakteristická monotónnost sídlištních celků se začíná vytrácet a přetváří se v sít kiosků sledující pohyb a potřeby obyvatel. Objevují se tak svébytná centra na periferiích měst.

\section{SOUPIS ZDROJU゚}

Asabashvili, Levan - Mirzikashvili, Rusudan. Post war housing in Georgia. Fitch colloquium: Why Preserve Public Housing, conducted at the Columbia University. http://urbanreactor.blogspot.cz/2012/04/post-war-housing-in-georgia.html 
Ghenciulescu, Stefan - Goagea, Constantin - Vockler, Kai. Scenarios for the collective housing from the socialist period in Bucharest. Bucharest: Zeppelin, 2009. ISBN 978-973-0-06942-6.

HALÍK, Pavel. Počátky a proměny současné urbanistické scény. In: Halík, Pavel - Kratochvíl, Petr - Nový, Otakar. Architektura a město. Praha: Akademia, 1998. ISBN 800-200-0665-6.

MUSIL, J. a kol. Lidé a sídliště. Praha: Nakladatelství Svoboda, 1985. ISBN 73/508-21-8.5.

\section{FOTOGRAFIE}

Foto: archiv autora 


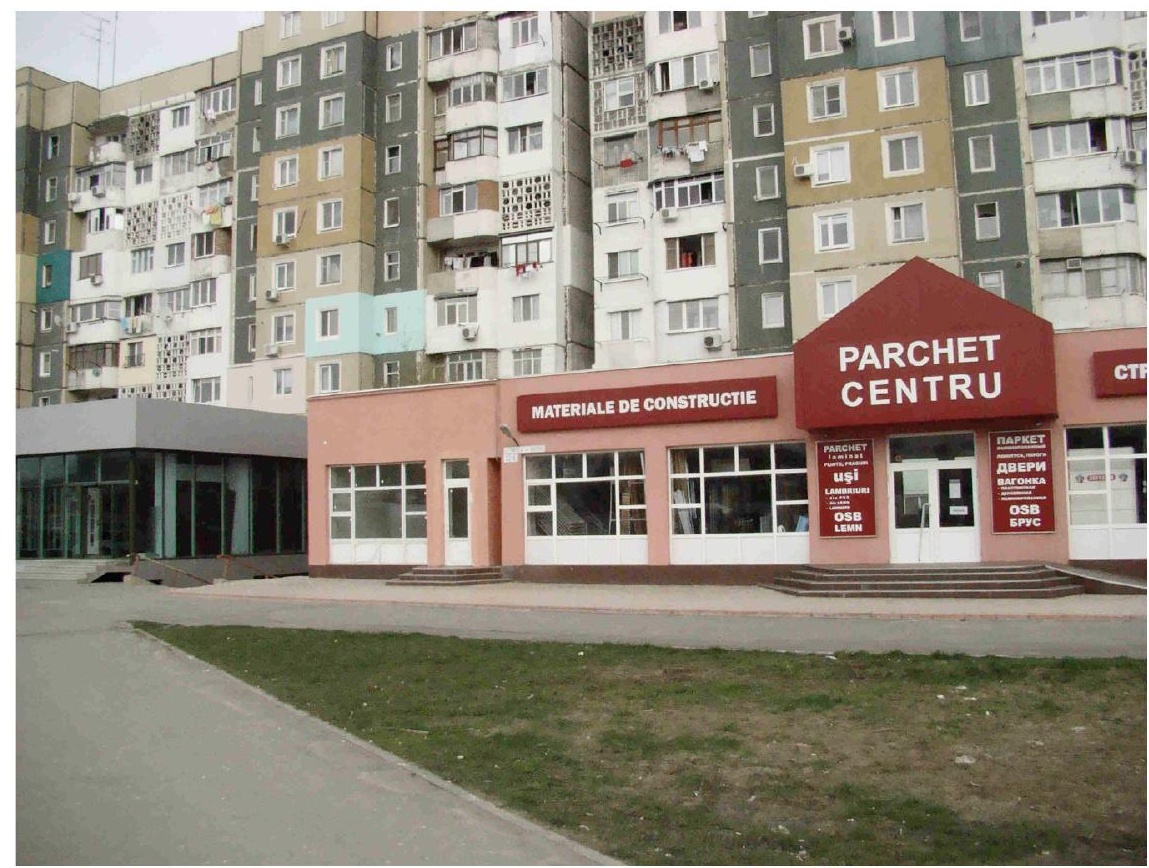

2

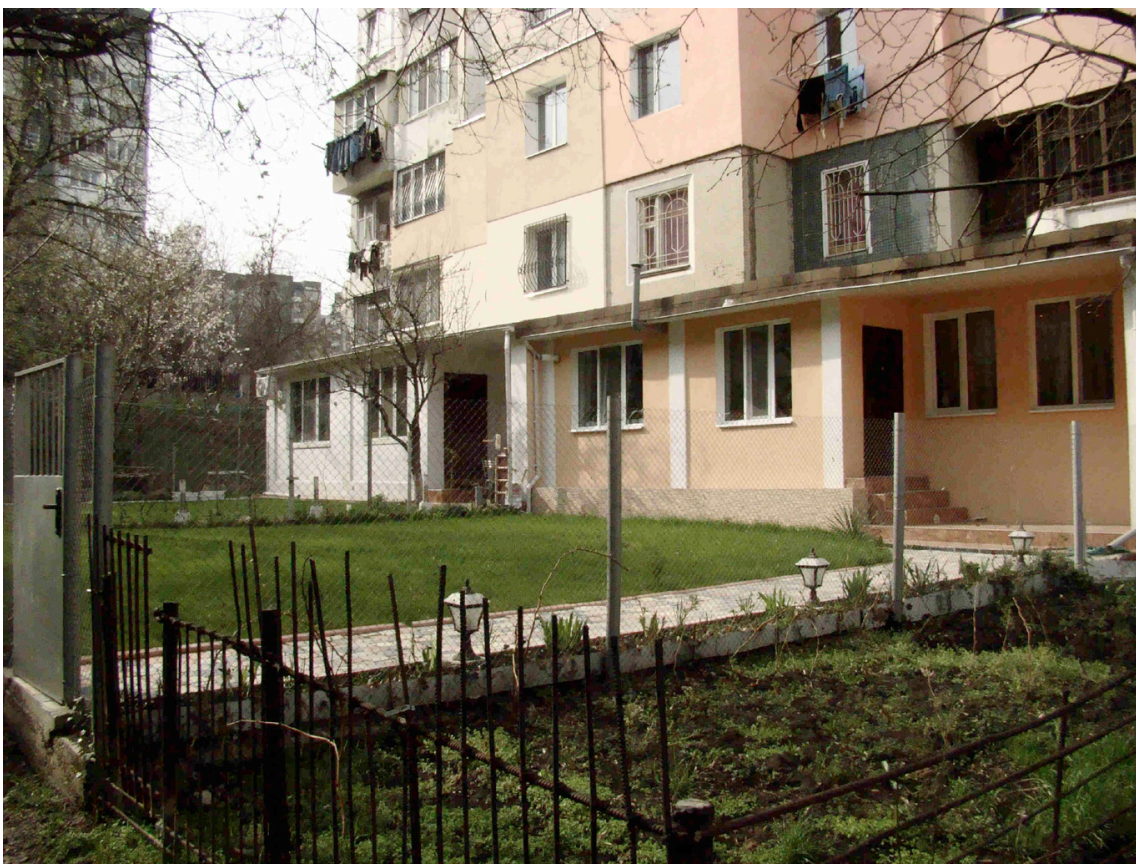

